\title{
Inhibition of carbon steel corrosion and hydrogen penetration into the metal in media containing $\mathrm{H}_{2} \mathrm{~S}$ and $\mathrm{CO}_{2}$
}

\author{
V. I. Vigdorovich, ${ }^{1}$ L. E. Tsygankova ${ }^{2}$ and N.V. Shel ${ }^{1}$ \\ ${ }^{1}$ Tambov State Technical University, ul. Internatsional'naya 33, Tambov, \\ 392622 Russian Federation \\ ${ }^{2}$ Derzhavin State University, ul. Sovetskaya 106, Tambov, 392000 Russian Federation \\ E-mail: vits21@mail.ru
}

\begin{abstract}
The efficiency of EM-9 product as a versatile inhibitor against carbon steel corrosion and hydrogen penetration into the metal in slightly acidic chloride-containing media $(\mathrm{pH}=2-$ 4; $50 \mathrm{~g} / 1 \mathrm{NaCl}$ ) containing hydrogen sulfide and carbon dioxide separately and in combination has been investigated. The EM-9 formulation is a process mixture of polyaminoimidazolines, products of the reaction of tetraethylene pentamine with tall oil acids.

The bactericidal properties of the inhibitor have been investigated. The bactericidal ability of the inhibitor with respect to sulfate reducing bacteria (SRB) was estimated by two methods: $i$ ) reduction in the number of the microorganisms, ii) retardation of $\mathrm{H}_{2} \mathrm{~S}$ formation by the microorganisms (iodometric titration).

The inhibitor favors the preservation of the mechanical properties of $\mathrm{St} 3$ and $65 \mathrm{G}$ steels under the same conditions and slows down the hydrogen diffusion across a St3 steel membrane. The latter was evaluated in an electrochemical hydrogen permeation Devanathan-type cell. The qualitative correlation between the slowdown of hydrogen diffusion through the steel membrane by the inhibitor and the preservation of the mechanical properties of steel in the presence of the inhibitor has been shown. The mechanical properties of steel have been estimated under conditions of stretching and bending stress after corrosion tests in uninhibited and inhibited solutions for 24 hours.

Thus, EM-9 is a versatile inhibitor that slows down the corrosion of carbon steel and hydrogen penetration into the metal in media containing $\mathrm{H}_{2} \mathrm{~S}$ and $\mathrm{CO}_{2}$ separately or in combination. It shows a high bactericidal activity and the ability to preserve the mechanical properties of steel.
\end{abstract}

Keywords: inhibition, retardation, hydrogen diffusion, mechanical test, bactericide.

Received: August 11, 2012.

doi: $\underline{10.17675 / 2305-6894-2012-1-1-038-050}$

\section{Introduction}

The scope of metal corrosion inhibitors for various media is sufficiently wide [1-10] and expands continuously. At the same time, many inhibitors are generally provided as preliminary laboratory samples or have only a limited applicability. Development of 
versatile corrosion inhibitors is currently expedient. A versatile inhibitor can slow down a few types of corrosion effects simultaneously or counteract the adverse effect of a number of corrosion stimulators $\left(\mathrm{H}^{+}, \mathrm{O}_{2}, \mathrm{H}_{2} \mathrm{~S}, \mathrm{CO}_{2}\right)$ that play the role of cathodic depolarizers:

$$
\begin{gathered}
\mathrm{H}^{+}+e \rightarrow \mathrm{H}_{\text {ads }} \\
\mathrm{O}_{2}+4 \mathrm{H}_{3} \mathrm{O}^{+}+4 e \rightarrow 6 \mathrm{H}_{2} \mathrm{O} \\
\mathrm{H}_{2} \mathrm{~S}+2 e \rightarrow 2 \mathrm{H}_{\text {ads }}+\mathrm{S}_{\text {ads }}^{2-} \\
\mathrm{H}_{2} \mathrm{~S}+e \rightarrow \mathrm{H}_{\mathrm{ads}}+\mathrm{HS}_{\mathrm{ads}}^{-} \\
\mathrm{HCO}_{3}^{-}+2 e \rightarrow 2 \mathrm{H}_{\mathrm{ads}}+\mathrm{CO}_{3}^{2-}
\end{gathered}
$$

Processes (1) and (3) - (5) promote the metal hydrogen pickup and hydrogen brittleness.

Principal significance is given to minimization of corrosion inhibitor concentration and provision of raw materials and facilities for the production of inhibitors.

Investigation of hydrogen diffusion through a steel membrane is widely used to study the formation mechanism of its flux through the metal [11]. This method is also used to estimate the retardation of the hydrogen induced degradation of metal materials by an inhibitor [12]. However, the opinion exists that there is no relationship between the hydrogen diffusion flux through the metal membrane and its hydrogen induced degradation and hydrogen brittleness [13]. We did not find investigations confirming or refuting straightly or indirectly the existence of such a connection. Meanwhile, this problem presents an essential theoretical and practical interest. Therefore, besides the estimation of hydrogen entry into the metal as a function of the inhibitor presence and concentration, the change in the mechanical properties of steel should be investigated.

The aim of the present work is to estimate the possibility of preparation of versatile inhibitors against carbon steel corrosion and hydrogen entry into the metal in media containing hydrogen sulfide and carbon dioxide by the example of EM-9 composition, which is a process mixture of polyaminoimidazolines - products of reaction between tetraethylene pentamine and tall oil acids.

\section{Experimental}

The corrosion resistance of St3 carbon steel (composition, wt.\%: Fe 98.36; C 0.2; Mn 0.5; Si 0.15 ; P 0.04; S 0.05; Cr 0.3; Ni 0.2; $\mathrm{Cu} 0.2$ ) was studied gravimetrically [14] at room temperature. Coupons with dimensions of $20 \times 12 \times 2 \mathrm{~mm}$ were polished to finish class 6 . The background solutions with $\mathrm{pH}$ equal to 2 and 4 contained $50 \mathrm{~g} / 1 \mathrm{NaCl}$. To introduce $\mathrm{H}_{2} \mathrm{~S}(25-100 \mathrm{mg} / \mathrm{l})$ into the corrosion media, the calculated quantities of $\mathrm{Na}_{2} \mathrm{~S}$ and $\mathrm{HCl}$ were added in accordance with the reaction

$$
\mathrm{Na}_{2} \mathrm{~S}+2 \mathrm{HCl} \rightarrow 2 \mathrm{NaCl}+\mathrm{H}_{2} \mathrm{~S}
$$


The corrosion tests and electrochemical measurements were carried out in polyethylene cells provided with valves for creating the equilibrium partial pressure of $\mathrm{CO}_{2}$ $(100 \mathrm{kPa})$ in the gas phase [15]. Carbon dioxide was introduced under pressure-gauge control throughout the experiment. The protective effect of the inhibitor $\mathrm{Z}$ was calculated by the formula

$$
Z(\%)=100\left(K_{0}-K\right) / K_{0},
$$

where $\mathrm{K}_{0}$ and $\mathrm{K}$ are the corrosion rates in the solutions without and with the inhibitor, respectively. Duration of the corrosion tests was 24 hours. The polarization potentiostatic measurements were performed in a three-electrode cell (pyrex) with divided anode and cathode compartments. The working electrode surface was polished with abrasive paper and degreased with acetone. The counter electrode was Pt. The potentials were measured relative to the saturated silver/silver-chloride electrode and converted to the normal hydrogen scale. The hydrogen diffusion across a $300 \mu \mathrm{m} \mathrm{St} 3$ steel membrane $\left(3.63 \mathrm{~cm}^{2}\right.$ in area) was evaluated in an electrochemical hydrogen permeation Devanathan-type cell (pyrex) according to $[16,17]$. The exit compartment of the cell contained the titrated permanganate solution, which completely oxidized hydrogen diffusing across the membrane. The hydrogen diffusion flux $\left(i_{\mathrm{H}}\right)$ was estimated from the decrease in the permanganate concentration. The duration of the permeation experiment was 2 hours. To estimate the suppression of the hydrogen diffusion flux through the membrane by the inhibitor, we used the coefficient

$$
\gamma=i_{0, H} / i_{H}
$$

where $i_{0, \mathrm{H}}$ and $i_{\mathrm{H}}$ are the hydrogen diffusion flux through the steel membrane in the uninhibited and inhibited solutions, respectively. $\gamma>1$ corresponds to the suppression of hydrogen permeation; on the contrary, $\gamma<1$ corresponds to stimulation. The investigation of the bactericidal ability of the inhibitor with respect to sulfate reducing bacteria (SRB) was conducted in the Postgeit nutritious medium with the composition, $\mathrm{g} / \mathrm{l}: \mathrm{NH}_{4} \mathrm{Cl}-1.0$; $\mathrm{K}_{2} \mathrm{HPO}_{4}-0.5 ; \mathrm{MgSO}_{4} \cdot 7 \mathrm{H}_{2} \mathrm{O}-2.0 ; \mathrm{Na}_{2} \mathrm{SO}_{4}-0.5 ; \mathrm{CaCl}_{2}-0.1$; calcium lactate -3.5 ; yeast extract $-1 \mathrm{mg} / \mathrm{l}$. Bactericidal efficiency with respect to SRB (Desulfovibrio desulfuricans) was estimated by two parameters:

- suppression of the number of microorganisms according to the formula

$$
S(\%)=100\left(N_{0}-N\right) / N_{0},
$$

where $N_{0}$ and $N$ are the bacteria counts in the non-inhibited and inhibited solution, respectively;

- retardation of the $\mathrm{H}_{2} \mathrm{~S}$ formation by the microorganisms (iodometric titration).

The change in the mechanical properties of steels was studied under stretching stress (St3, INSTRON 5565 facility) and bending stress (spring steel 65G with composition, wt.\%: $\mathrm{C}-0.65 ; \mathrm{S}-0.23 ; \mathrm{Mn}-1.05 ; \mathrm{Cr}-0.2 ; \mathrm{Fe}-$ balance; the NG-3M facility was used 
for the bending tests of the bars). In the first case, St3 steel proportionate plane samples with a length of $150 \mathrm{~mm}$ and a cross-section area of $5 \mathrm{~mm}^{2}$ polished to finish class 6 were used. Their dimensions were, $\mathrm{mm}: a_{0}-0.5 ; b_{0}-10 ; l_{0}-25 ; l-30 ; h-40 ; r-25 ; d-10$; $L_{1}-110 ; L-150$ (Fig. 1). In the second case, plates with dimensions of $110 \times 8 \times 0.5 \mathrm{~mm}$ were preliminarily burnt with cast iron chips at $t=850^{\circ} \mathrm{C}$ with followed by tempering in an oil at $t=200^{\circ} \mathrm{C}$ and cooling together with the cooling furnace. The steel samples were placed in the uninhibited and inhibited corrosion media for 24 hours and then exposed to the mechanical tests. The mechanical tests were duplicated six times.

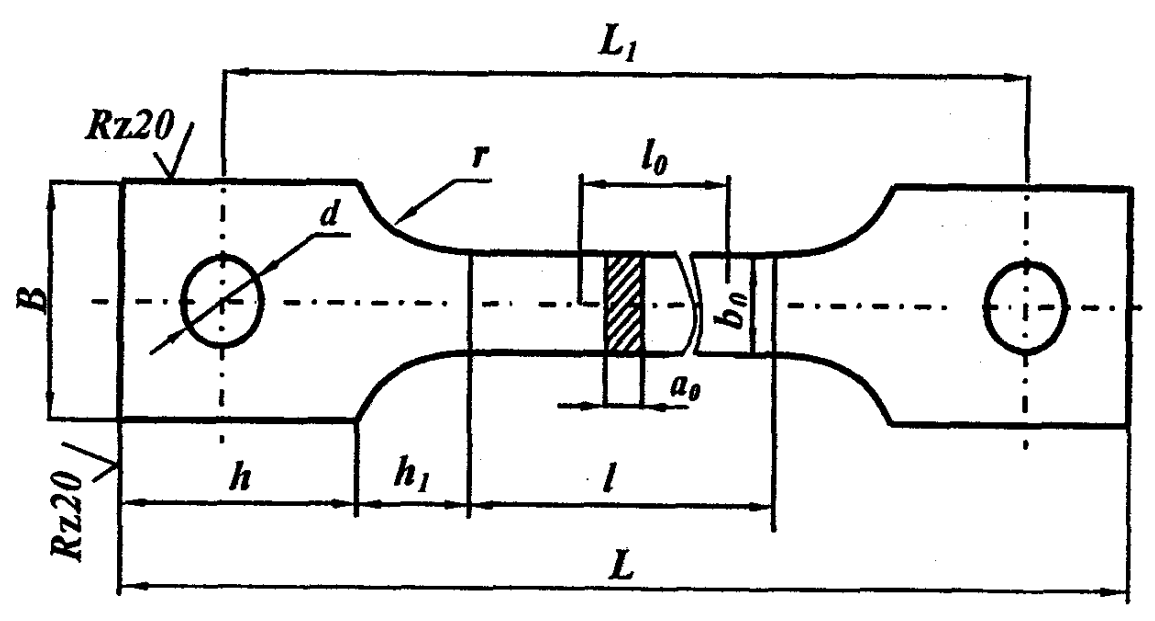

Fig. 1. Shape of a sample for the estimation of the mechanical properties of steel under stretching stress.

\section{Results and discussion}

\section{Bactericidal efficiency of the inhibitor}

The bactericidal activity of EM-9 is rather high. Even in the Postgeit nutritious medium, where SRB have the most comfortable conditions for their vital functions, $\mathrm{S}$ reaches $82 \%$ at the inhibitor concentration of $200 \mathrm{mg} / \mathrm{l}$ (Table 1).

Table 1. The bactericidal efficiency (S) of EM-9 for SRB in the Postgeit medium

\begin{tabular}{cc}
\hline Concentration of EM-9 $(\mathbf{m g} / \mathbf{l})$ & $\boldsymbol{S}(\mathbf{\%})$ \\
\hline 25 & 73 \\
50 & 75 \\
100 & 77 \\
200 & 82 \\
\hline
\end{tabular}

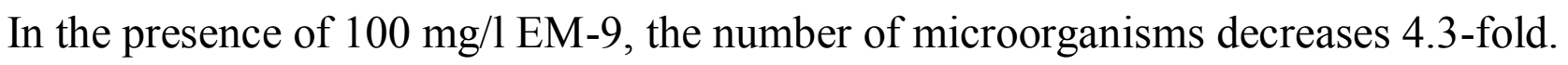


The high bactericidal efficiency of EM-9 is confirmed by a study of the $\mathrm{H}_{2} \mathrm{~S}$ quantity formed by the microorganisms in time (Fig. 2). The presence of just $25 \mathrm{mg} / \mathrm{l}$ of the inhibitor sharply decreases the $\mathrm{H}_{2} \mathrm{~S}$ formation by the microorganisms and prevents the onset of the so-called exponential phase of their growth (Fig. 2, curves 1 and 2). A subsequent increase in $\mathrm{C}_{\mathrm{EM}-9}$ retards the $\mathrm{H}_{2} \mathrm{~S}$ formation even more, but the effect of 50 and $200 \mathrm{mg} / \mathrm{l} \mathrm{EM}-9$ is practically the same.

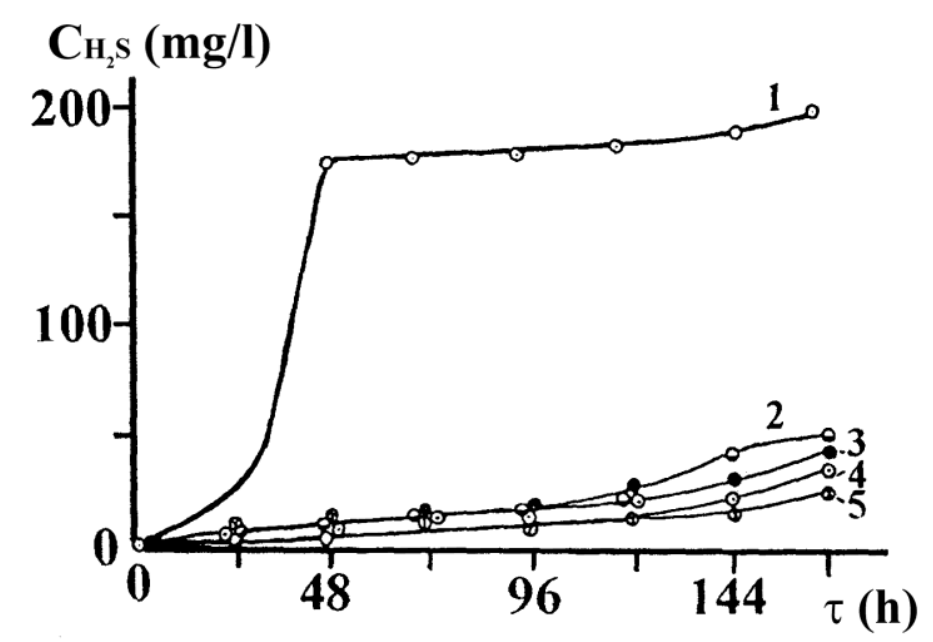

Fig. 2. Effect of EM-9 concentration and test duration on $\mathrm{H}_{2} \mathrm{~S}$ production by $\mathrm{SRB}$ in the Postgeit nutritious medium. $C_{\mathrm{EM}-9}(\mathrm{mg} / \mathrm{l}): 1-0 ; 2-25 ; 3-50 ; 4-100 ; 5-200$.

\section{Gravimetrical test results}

Let us first note the absence of a common opinion on inhibitor classification based on protective efficiency, in particular, the $Z$ value. An attractive approach was suggested in [18]. Here we suggest to use the following scale (Table 2).

Table 2. Correlation between $Z$ and inhibitor characteristics

\begin{tabular}{cc}
\hline $\boldsymbol{Z}(\boldsymbol{\%})$ & Inhibitor characteristics \\
$Z \geq 90$ & excellent \\
$75 \leq Z \leq 89$ & good \\
$50 \leq Z \leq 74$ & average \\
$Z<50$ & weak \\
\hline
\end{tabular}

Carbonic acid media. At $\mathrm{pH}=2$, the $Z$ of EM-9 is near $80 \%$ in the presence of oxygen in solutions, but at $\mathrm{pH}=4$ it decreases by $15-20 \%$ (Fig. 3). In the absence of oxygen, $Z$ increases to $88 \%(\mathrm{pH}=2)$ or $82 \%(\mathrm{pH}=4)$ at the inhibitor concentration of $200 \mathrm{mg} / \mathrm{l}$. 
Hydrogen sulfide media. In the presence of $25 \mathrm{mg} / 1 \mathrm{H}_{2} \mathrm{~S}, \mathrm{~d} Z / \mathrm{d} C_{\text {Inh }}>0$ and $\mathrm{d} Z / \mathrm{dpH}<0$ (Table 3). At $C_{\mathrm{H}_{2} \mathrm{~S}}=50$ and $100 \mathrm{mg} / \mathrm{l}$, the results are qualitatively the same. At $\mathrm{pH}=2, Z$ values above $80 \%$ are achieved more easily. In media containing both $\mathrm{H}_{2} \mathrm{~S}(100 \mathrm{mg} / \mathrm{l})$ and $\mathrm{CO}_{2}\left(\mathrm{P}=10^{5} \mathrm{~Pa}\right)$, the protective efficiency of EM-9 is higher than $80 \%$ at $\mathrm{pH}=2$ and is near $80 \%$ at $\mathrm{pH}=4$ (Table 4 ).

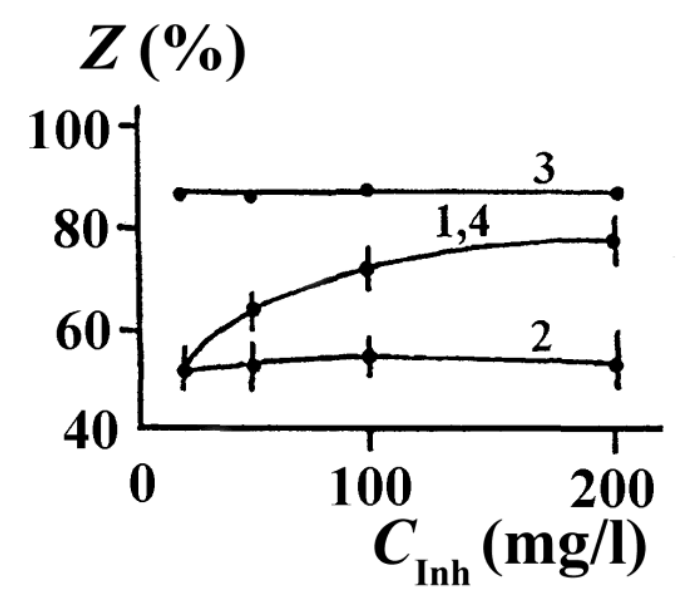

Fig. 3. Effect of $\mathrm{pH}$ and EM-9 concentration on its protection efficiency against carbon steel corrosion in solutions containing $50 \mathrm{~g} / 1 \mathrm{NaCl}$ and $\mathrm{CO}_{2}\left(P=10^{5} \mathrm{~Pa}\right)$, with $(1,2)$ and without oxygen $(3,4)$. pH: 1 and $3-2 ; 2$ and $4-4$.

Table 3. Effect of $\mathrm{pH}$ and inhibitor concentration on protective efficiency $(Z, \%)$ with respect to carbon steel corrosion in solutions containing oxygen, $50 \mathrm{~g} / 1 \mathrm{NaCl}$, and $\mathrm{H}_{2} \mathrm{~S}$.

\begin{tabular}{|c|c|c|c|c|}
\hline \multirow{2}{*}{$C_{\text {Inh }}(\mathrm{mg} / \mathrm{l})$} & \multirow{2}{*}{ pH } & \multicolumn{3}{|c|}{$Z(\%)$ at $C_{\mathrm{H}_{2} \mathrm{~S}}(\mathrm{mg} / \mathrm{l})$} \\
\hline & & 25 & $\mathbf{5 0}$ & 100 \\
\hline \multirow{2}{*}{20} & 2 & 59 & 82 & 78 \\
\hline & 4 & 49 & 55 & 54 \\
\hline \multirow[b]{2}{*}{50} & 2 & 66 & 84 & 83 \\
\hline & 4 & 56 & 72 & 57 \\
\hline \multirow[b]{2}{*}{100} & 2 & 69 & 87 & 84 \\
\hline & 4 & 61 & 73 & 66 \\
\hline \multirow{2}{*}{200} & 2 & 74 & 88 & 84 \\
\hline & 4 & 62 & 81 & 80 \\
\hline
\end{tabular}


Table 4. Effect of $\mathrm{pH}$ and inhibitor concentration on protective efficiency $(Z, \%)$ with respect to carbon steel corrosion in solutions containing oxygen, $50 \mathrm{~g} / 1 \mathrm{NaCl}, 100 \mathrm{mg} / \mathrm{l}$ $\mathrm{H}_{2} \mathrm{~S}$, and $\mathrm{CO}_{2}\left(P=10^{5} \mathrm{~Pa}\right)$.

\begin{tabular}{ccc}
\hline $\boldsymbol{C}_{\text {Inh }}(\mathbf{m g} / \mathbf{l})$ & $\mathbf{p H}$ & $\boldsymbol{Z}(\mathbf{\%})$ \\
\hline \multirow{2}{*}{20} & 2 & 85 \\
& 4 & 56 \\
50 & 2 & 89 \\
& 4 & 78 \\
\multirow{2}{*}{100} & 2 & 89 \\
& 4 & 78 \\
200 & 2 & 91 \\
& 4 & 82 \\
\hline
\end{tabular}

\section{Polarization measurements}

In the presence of $\mathrm{CO}_{2}\left(P=10^{5} \mathrm{~Pa}\right)$ and oxygen $(\mathrm{pH}=2)$, the inhibitor $(20 \mathrm{mg} / \mathrm{l})$ stimulates the cathodic reaction in the region of small cathodic polarization and retards it at $E<-0.18 \mathrm{~V}$, but these effects are small. Simultaneously, EM-9 sharply retards the anodic reaction. A further increase in $C_{\text {Inh }}$ does not affect the kinetics of partial electrode reactions. In the presence of $\mathrm{H}_{2} \mathrm{~S}$, the inhibitor slightly retards the cathodic reaction and essentially slows down the anodic one (Fig. 4).

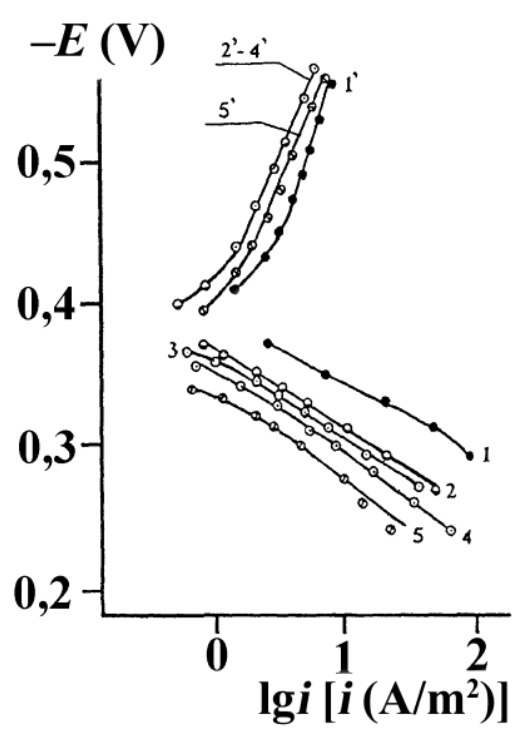

Fig. 4. Potentiostatic polarization curves of $\mathrm{St} 3$ steel in solutions with $\mathrm{pH}=2$ containing $50 \mathrm{~g} / 1$ $\mathrm{NaCl}$ and $100 \mathrm{mg} / 1 \mathrm{H} \mathrm{H}_{2} \mathrm{~S}$ in the presence of oxygen without $\left(1,1^{\prime}\right)$ and with the inhibitor $(\mathrm{mg} / \mathrm{l})$ : $2,2^{\prime}-20 ; 3,3^{\prime}-50 ; 4,4^{\prime}-100 ; 5,5^{\prime}-200$. 
At $\mathrm{pH}=4$ in the presence of $\mathrm{H}_{2} \mathrm{~S}$ or $\mathrm{CO}_{2}$, the cathodic reaction is accelerated and the anodic one is retarded upon addition of the inhibitor. In the presence of both $\mathrm{H}_{2} \mathrm{~S}$ and $\mathrm{CO}_{2}$ in combination, the inhibitor slows down the anodic ionization of the metal at all the concentrations tested, whereas the cathodic reaction slows down only at $C_{\text {Inh }}=20 \mathrm{mg} / 1$ (Fig. 5).

\section{Results of hydrogen permeation experiments}

The inhibitor retards the hydrogen diffusion flux into the steel membrane in the solutions studied. Its efficiency increases with an increase in its concentration and a decrease in the $\mathrm{pH}$ of the media (Table 5). In the solutions with $\mathrm{pH}=2$, the inhibitor at a concentration of $100 \mathrm{mg} / 1$ decreases hydrogen diffusion $15-32$ fold.

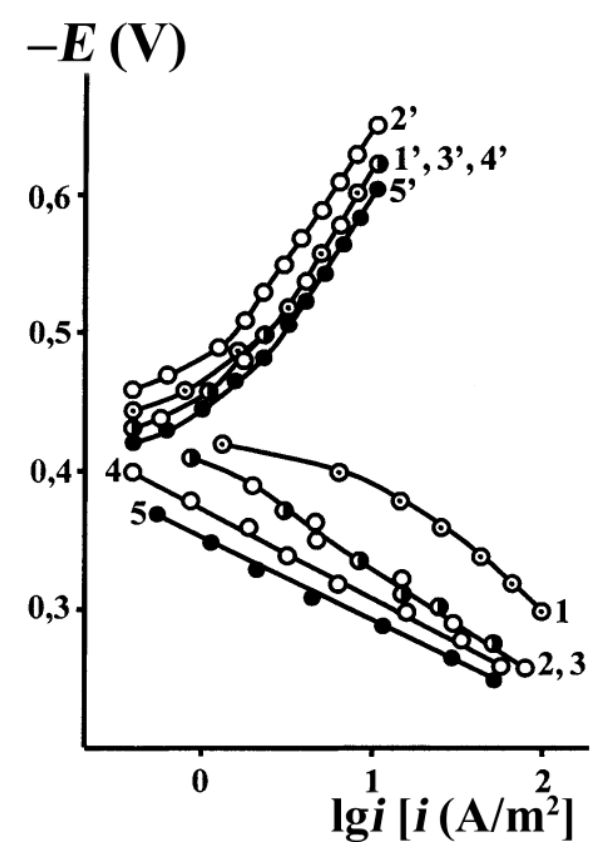

Fig. 5. Potentiostatic polarization curves of $\mathrm{St} 3$ steel in the solutions with $\mathrm{pH}=4$ containing $50 \mathrm{~g} / 1 \mathrm{NaCl}, 100 \mathrm{mg} / 1 \mathrm{H}_{2} \mathrm{~S}$ and $\mathrm{CO}_{2}\left(P=10^{5} \mathrm{~Pa}\right)$ in the presence of oxygen without $\left(1,1^{\prime}\right)$ and with the inhibitor $(\mathrm{mg} / \mathrm{l}): 2,2^{\prime}-20 ; 3,3^{\prime}-50 ; 4,4^{\prime}-100 ; 5,5^{\prime}-200$.

Table 5. Effect of the inhibitor concentration and $\mathrm{pH}$ on the $\gamma$ value in the solutions studied.

\begin{tabular}{|c|c|c|c|c|}
\hline \multirow{2}{*}{$C_{\text {EM-9 }}(\mathrm{mg} / \mathrm{l})$} & \multirow{2}{*}{ pH } & \multicolumn{3}{|c|}{$\gamma$ in solutions containing: } \\
\hline & & $\mathrm{CO}_{2}\left(10^{5} \mathrm{~Pa}\right)$ & $25 \mathrm{mg} / \mathrm{l} \mathrm{H}_{2} \mathrm{~S}$ & $\mathrm{CO}_{2}+100 \mathrm{mg} / \mathrm{l} \mathrm{H} \mathrm{H}_{2} \mathrm{~S}$ \\
\hline \multirow{2}{*}{20} & 2 & 1.3 & 11.0 & 6.5 \\
\hline & 4 & 1.2 & 1.9 & - \\
\hline \multirow{2}{*}{100} & 2 & 15.0 & 32.0 & 30.0 \\
\hline & 4 & 1.2 & 3.0 & - \\
\hline
\end{tabular}


Let us compare these results with the data of mechanical tests. The coefficient of firmness loss of the steel sample at the gap was calculated by the formula

$$
K_{g}(\%)=100\left(\sigma_{0}-\sigma\right) / \sigma_{0} ;
$$

for the bending strength tests the following equation was used:

$$
K_{b}(\%)=100\left(n_{0}-n\right) / n_{0},
$$

where $\sigma_{0}$ and $\sigma$ are the breaking points of St3 steel untreated and treated with the corrosion medium for $24 \mathrm{~h}$, respectively; $n_{0}$ and $n$ are the numbers of bends until the destruction of $65 \mathrm{G}$ steel samples untreated and treated for $24 \mathrm{~h}$ with the corrosion medium, respectively; $K_{g}$ and $K_{b}$ are the coefficients of firmness loss.

A typical "tension-deformation" diagram for steel samples untreated with the corrosion medium is shown in Fig. 6. Point $A$ corresponds to the breaking point. It is equal to $980 \mathrm{MPa}\left(1 \mathrm{~kg} / \mathrm{mm}^{2}=10 \mathrm{MPa}\right)$ for the initial sample (not exposed to the solution). After exposure of the samples to the solution with $\mathrm{pH}=4$ and $C_{\mathrm{H}_{2} \mathrm{~S}}=100 \mathrm{mg} / \mathrm{l}$, the breaking point diminishes to $660 \mathrm{MPa}$. The presence of the inhibitor in the solution containing $\mathrm{CO}_{2}$ increases the breaking point in comparison with the uninhibited solution (Fig. 7). The effect of the inhibitor concentration is more pronounced at $\mathrm{pH}=4$. In solutions containing $\mathrm{H}_{2} \mathrm{~S}$, the drop of the breaking point is more essential. Correspondingly, the efficiency of the inhibitor increases and its concentration effect is more pronounced. A qualitatively similar picture is observed in the presence of $\mathrm{CO}_{2}$ and $\mathrm{H}_{2} \mathrm{~S}$ in combination (Fig. 8).

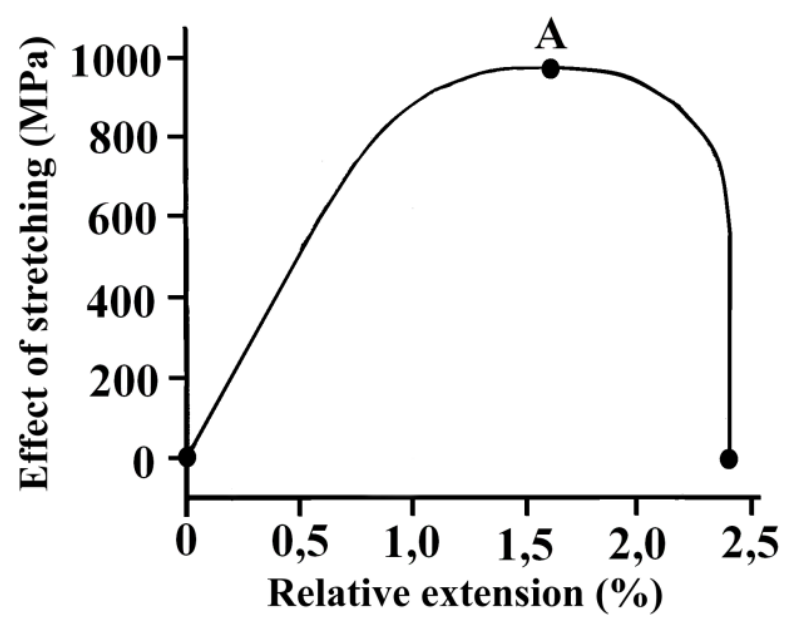

Fig. 6. A typical "tension - deformation" diagram for the initial steel sample not treated with the corrosion medium. 


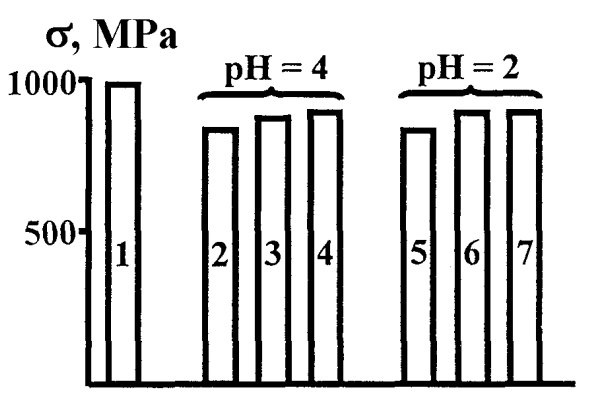

Fig. 7. Dependence of the breaking point upon stretching of St 3 steel samples on the inhibitor concentration in the solution with $50 \mathrm{~g} / 1 \mathrm{NaCl}$ and a $\mathrm{CO}_{2}$ excess partial pressure of $10^{5} \mathrm{~Pa}$ after exposure for 24 h. 1 - without exposure; 2, 5-in non-inhibited solutions; 3, 4, 6, 7 - in the inhibited solutions with $C_{\text {Inh }}(\mathrm{mg} / \mathrm{l}): 3,6-20 ; 4,7-100$.

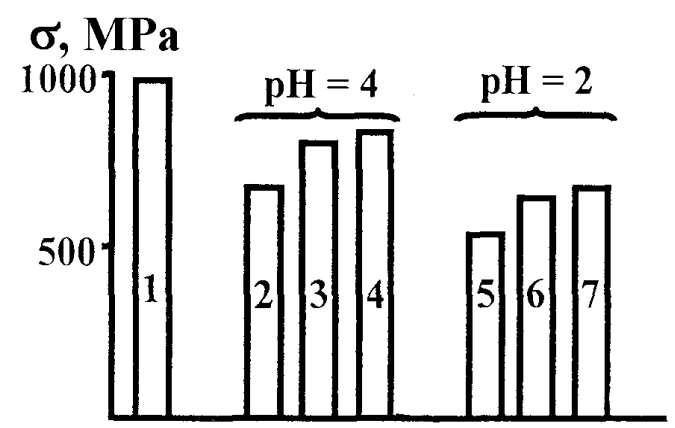

Fig. 8. Dependence of the breaking point upon stretching of St3 steel samples on the inhibitor concentration in the solution with $50 \mathrm{~g} / \mathrm{l} \mathrm{NaCl}, 100 \mathrm{mg} / 1 \mathrm{H}_{2} \mathrm{~S}$ and a $\mathrm{CO}_{2}$ excess partial pressure of $10^{5} \mathrm{~Pa}$ after exposure for $24 \mathrm{~h} .1$ - without exposure; 2,5 - in the uninhibited solutions; $3,4,6,7-$ in inhibited solutions with $C_{\mathrm{Inh}}(\mathrm{mg} / \mathrm{l}): 3,6-20 ; 4,7-100$.

The inhibition of the corrosion medium and subsequent execution of the mechanical tests of St $65 \mathrm{G}$ samples by means of bending strain show a more essential effect (Fig. 9) that is evidently conditioned by the character of the strains and the chemical composition and the physical properties of steels.

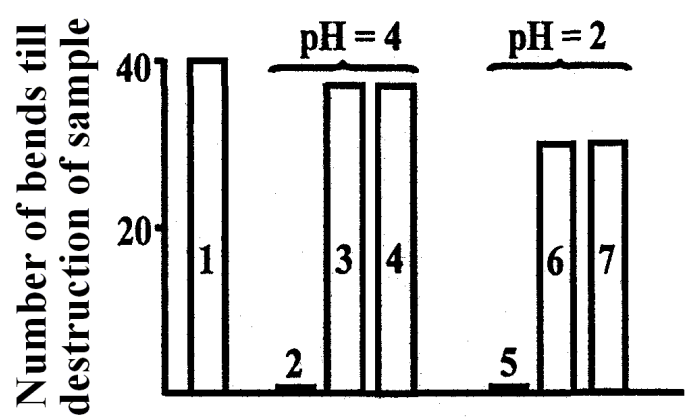

Fig. 9. Dependence of the number of bends of St $65 \mathrm{G}$ steel samples till their destruction on the inhibitor concentration in the solutions with $50 \mathrm{~g} / \mathrm{l} \mathrm{NaCl}$ and $100 \mathrm{mg} / 1 \mathrm{H}_{2} \mathrm{~S}$ after exposure for $24 \mathrm{~h}$. The rest of the designations are the same as in Fig. 8. 
The effect of the inhibitor on the preservation of the steel mechanical properties under stretching and bending strain conditions is shown in Table 6.

Comparison of data in Tables 5 and 6 shows that a correlation exists between the retardation of hydrogen diffusion through a steel membrane and the increase in the breaking point of the steel on a gap and a bend in the presence of the inhibitor. In fact, at $C_{\text {Inh }}=100 \mathrm{mg} / 1$ in the solution containing $100 \mathrm{mg} / 1 \mathrm{H}_{2} \mathrm{~S}$ and $\mathrm{CO}_{2}(\mathrm{pH}=2)$, the hydrogen diffusion flux through the St3 membrane decreases 30 -fold and simultaneously the value of the firmness loss coefficient on a gap decreases from 18 to $7 \%$. An analogous correlation is observed in media with $\mathrm{pH}=4$.

The versatility of the inhibitors, i.e., the capability to retard the hydrogen sulfide corrosion, carbon dioxide corrosion and hydrogen pickup of steel along with bactericidal efficiency allows one a more efficient and less expensive variant of metal protection against corrosion to be provided in oil producing and petrochemical industry.

Table 6. Dependence of the coefficients of firmness loss of steel under the conditions of stretching and bending strain calculated according to formulas (6) and (7) on the corrosion media composition and inhibitor concentration.

\begin{tabular}{|c|c|c|c|c|c|}
\hline \multirow{2}{*}{$\begin{array}{c}\text { Type of } \\
\text { mechanical } \\
\text { tests }\end{array}$} & \multirow[t]{2}{*}{$C_{\text {Inh }}(\mathrm{mg} / \mathrm{l})$} & \multirow[t]{2}{*}{$\begin{array}{l}\text { pH of the } \\
\text { medium }\end{array}$} & \multicolumn{3}{|c|}{$\begin{array}{c}K_{i}(\%) \text { in the solutions with } 50 \mathrm{mg} / \mathrm{l} \mathrm{NaCl} \\
\text { and additives: }\end{array}$} \\
\hline & & & $\begin{array}{c}100 \mathrm{mg} / \mathrm{l} \\
\mathrm{H}_{2} \mathrm{~S}\end{array}$ & $P_{\mathrm{CO}_{2}}=10^{5} \mathrm{~Pa}$ & $\begin{array}{c}100 \mathrm{mg} / \mathrm{l} \mathrm{H}_{2} \mathrm{~S}+ \\
P_{\mathrm{CO}_{2}}=10^{5} \mathrm{~Pa}\end{array}$ \\
\hline \multirow{6}{*}{ stretching } & \multirow{2}{*}{0} & 4 & 33 & 12 & 10 \\
\hline & & 2 & 45 & 15 & 18 \\
\hline & \multirow{2}{*}{20} & 4 & 18 & 11 & 6 \\
\hline & & 2 & 35 & 9 & 7 \\
\hline & \multirow{2}{*}{100} & 4 & 17 & 9 & 7 \\
\hline & & 2 & 32 & 9 & 7 \\
\hline \multirow{6}{*}{ bending } & \multirow{2}{*}{0} & 4 & 98 & 73 & 99 \\
\hline & & 2 & 98 & - & 93 \\
\hline & \multirow{2}{*}{20} & 4 & 5 & 52 & 5 \\
\hline & & 2 & 35 & 58 & 20 \\
\hline & \multirow{2}{*}{100} & 4 & 5 & 45 & 2 \\
\hline & & 2 & 35 & 30 & 12 \\
\hline
\end{tabular}

According to our data $[12,15,19]$ including the present investigation, versatile nitrogencontaining inhibitors (polyamines, imidazolines) generally suppress the anodic reaction of metal ionization essentially but affect only slightly the cathodic process kinetics. 
Depending on the nature of the medium, either a slow-down or acceleration of reduction of the cathodic depolarizers is possible, while the corrosion rate decreases.

Acceleration of the cathodic process including reactions (1), (3)-(5) does not always promote the hydrogen diffusion into carbon steel, although it is often believed to be exactly so [11]. The point is that a removal of $\mathrm{H}_{\mathrm{ads}}$ is possible at least by two directions [20]:

$$
\begin{gathered}
\mathrm{H}_{\mathrm{ads}}+\mathrm{H}_{\mathrm{ads}} \rightarrow \mathrm{H}_{2} \\
\mathrm{H}_{\mathrm{ads}}+\mathrm{H}^{+}+e \rightarrow \mathrm{H}_{2} \\
\mathrm{H}_{\mathrm{ads}} \rightarrow \mathrm{H}_{\mathrm{abs}}
\end{gathered}
$$

An inhibitor accelerating reactions (1) or (3)-(5) can differently affect processes (8)-(9). If processes $(8 a)-(8 b)$ are accelerated to a greater extent than the hydrogen absorption process (9), hydrogen permeation will be retarded, and vice versa. The hydrogen permeation into a metal can aggravate its mechanical properties.

The results obtained in the present investigation testify that a qualitative correlation exists between the hydrogen diffusion flux into carbon steel and its firmness loss.

\section{Conclusions}

The possibility of preparation of versatile inhibitors retarding the corrosion of carbon steel and solid phase hydrogen diffusion in media containing $\mathrm{H}_{2} \mathrm{~S}$ and $\mathrm{CO}_{2}$ separately and in combination and demonstrating high bactericidal activity has been shown. EM-9 is such an inhibitor. It is more efficient in the presence of $\mathrm{H}_{2} \mathrm{~S}$ or $\mathrm{H}_{2} \mathrm{~S}+\mathrm{CO}_{2}$.

Addition of $100 \mathrm{mg} / 1 \mathrm{EM}-9$ into corrosive media makes it possible to lower the coefficient of firmness loss of carbon steel $2.0-2.5$ fold and that of spring steel more than 19-fold in the presence of $\mathrm{H}_{2} \mathrm{~S}$ and almost 50-fold in the presence of $\mathrm{H}_{2} \mathrm{~S}+\mathrm{CO}_{2}$. A qualitative correlation is observed between the retardation of the hydrogen diffusion flux through the membrane in the presence of the inhibitor and the preservation of the steel mechanical properties in inhibitor-containing media.

\section{References}

1. A. I. Altsybeeva and S. Z. Levin, Ingibitory korrozii metallov (Metal corrosion inhibitors), 1968, Leningrad, Khimiya (in Russian).

2. I. L. Rozenfel'd, Ingibitory korrozii (Corrosion inhibitors), 1977, Moscow, Khimiya (in Russian).

3. I. L. Rozenfeld and V. P. Persiantseva, Ingibitory atmosfernoi korrozii (Atmospheric corrosion inhibitors), 1985, Moscow, Nauka (in Russian).

4. L. S. Moiseeva, Zashchita Metallov, 1999, 35, 597 (in Russian).

5. Yu. I. Kuznetsov, L. V. Frolova and E. V. Tomina, Korroziya: materialy, zashchita, 2005, no. 6, 18 (in Russian). 
6. A. P. Efremov and S. K. Kim, Korroziya: materialy, zashchita, 2005, no. 10, 14 (in Russian).

7. V. I. Vigdorovich, Zashchita Metallov, 2000, 36, 541 (in Russian).

8. J. I. Bregman, Corrosion inhibitors 1963, New York, The Macmillan company; London, Collier-Macmillan Limited.

9. L. S. Moiseeva, S. A. Gurov and A. E. Aicin, Korroziya: materialy, zashchita, 2005, no. 4,35 .

10. L. S. Moiseeva, S. A. Gurov and A. E. Aicin, Korroziya: materialy, zashchita, 2005, no. $8,18$.

11. V. V. Kuznetsov, G. V. Khaldeev and V. I. Kichigin, Navodorozhivanie metallov $v$ elektrolitakh (Hydrogen absorption by metals in electrolytes), 1993, Moscow, Mashinostroenie (in Russian).

12. V. I. Vigdorovich, S. E. Siniutina and L. V. Chivilyova, Zashchita Metallov, 2000, 36, 607 (in Russian).

13. S. M. Beloglazov, Elektrohimicheskii vodorod $i$ metally. Povedeniye, bor'ba $s$ okhrupchivaniem (Electrochemical hydrogen and metals. Behavior and mitigation of embrittlement), 2004, Kaliningrad, KGU (in Russian).

14. V. V. Romanov, Metody issledovaniya korrozii metallov (Methods for the study of metal corrosion), 1965, Moscow, Metallurgiya (in Russian).

15. L. E. Tsygankova, V. I. Vigdorovich and N. V. Shel, Proc. $4^{\text {th }}$ Kurt Schwabe Corr. Symp. "Mechanisms of Corrosion and Corrosion Protection", Helsinki, Finland, June 2004, Helsinki University of Technology, 316.

16. N. V. Kardash and V. V. Batrakov, Zashchita Metallov, 1995, 31, 441 (in Russian).

17. N.V. Kardash and V.V. Batrakov, Zashchita Metallov, 2000, 36, 64 (in Russian).

18. A. B. Kichenko and V. M. Kushnarenko, Praktika Protivokorrozionnoi zaschity, 2005, 38, no. 4, 17 (in Russian).

19. L. E. Tsygankova, V. I. Vigdorovich and Ya. R. Naschyokina, Proc. Int. Conf. "Corrosion 2005”, Warsaw, Poland, June 2005, vol. 3, 23.

20. L. E. Tsygankova, V. I. Vigdorovich and M. V. Vigdorovich, Surf. Interf. Analysis, 2004, 36, 1083. 